Systematic Review

\title{
Can Unilateral Kyphoplasty Replace Bilateral Kyphoplasty in Treatment of Osteoporotic Vertebral Compression Fractures? A Systematic Review and Meta-analysis
}

Han Sun, MS, Pei-Pei Lu, MS, Yi-Jie Liu, MS, Xu Yang, MS, Ping-Hui Zhou, MD, Xiao-Feng Shen, MD, Si-Wei Sun, Ms, and Huilin Yang, MD, PhD

From: The First Affiliated Hospital of Soochow University

Department of Orthopaedics

Address Correspondence: The First Affiliated Hospital of Soochow University Department of Orthopaedics 188 Shizi Street Canglang District Suzhou, Jiangsu E-mail: yanghlsz@163.com

Disclaimer: There was no external funding in the preparation of this manuscript.

Conflict of interest: Each author certifies that he or she, or a member of his or her immediate family, has no commercial association

(i.e., consultancies, stock ownership, equity interest, patent/licensing arrangements, etc.) that

might pose a conflict of interest in connection with the submitted manuscript.

Manuscript received: 06-21-2015 Revised manuscript received: 12-26-2016

Accepted for publication: o1-04-2016

Free full manuscript: www.painphysicianjournal. com
Background: Kyphoplasty has been proven to be an efficient method to relieve patient suffering from osteoporotic vertebral compression fractures (OVCFs). Because of its technological superiority, unilateral kyphoplasty consumes less operative time and bone cement than traditional bilateral kyphoplasty. However, there is controversy about which method is most efficient in the treatment of OVCFs. Thus, an overall analysis should be performed to shed light on the facts corroborating both procedures.

Objective: To evaluate the safety and efficacy of unipedicular kyphoplasty versus bipedicular kyphoplasty in treating OVCFs.

Study Design: Inclusion criteria were randomized controlled trials focusing on comparing unilateral versus bilateral balloon kyphoplasty in treatment of OVCFs. The exclusion criteria contained infection, neoplastic etiology, traumatic fracture, neural compression, neurological deficit, spinal stenosis, previous surgery at the involved vertebral body, long-term use of steroids, and kyphoplasty with other invasive or semi-invasive intervention treatment. Retrospective studies, reviews, technology introductions, and biochemical trials were also excluded.

Settings: The PubMed MEDLINE, Cochrane Library, Web of Science, and EMBASE were systematic searched. Only randomized controlled trials published up to June 2015 comparing unilateral kyphoplasty with bilateral kyphoplasty in treatment of OVCFs were identified.

Methods: Two researchers independently screeded the works for inclusion and data extraction. The Grading of Recommendations, Assessment, Development, and Evaluation (GRADE) system was used to assess the methodological quality and evidence synthesis.

Results: Six articles with 563 patients were enrolled in this study. Results showed that the unilateral approach required less surgical time $(\mathrm{MD},-23.19 ; 95 \% \mathrm{Cl},[-27.08,-19.31] ; \mathrm{P}<0.00001)$ and cement consumption (MD, $-2.07 ; 95 \% \mathrm{Cl},[-2.23,-1.91] ; P<0.00001)$, as well as a reduced cement leakage ratio $(\mathrm{RR}, 0.59 ; 95 \% \mathrm{Cl},[0.35,0.99] ; \mathrm{P}<0.05)$ and improved short-term general health $(\mathrm{MD}, 1.48 ; 95 \% \mathrm{Cl}$, $[0.02,2.93], P<0.05)$. No significant difference was found in the visual analog scale score (short-term and long-term), Oswestry Disability Index score (mid-term and long-term) kyphotic angle reduction, restoration rate of anterior vertebral height, vertebral height loss rate, postoperative adjacent-level fractures, or in other assessments of 36-Item Short Form Health Survey parameters (short-term and long-term).

Limitations: Only 6 studies were included, so that the sample size was still relatively small and publication bias could not be revealed in this study. Observation time of some data was inconsistent. All of these problems could influence the reliability of the results.

Conclusion: Both unilateral kyphoplasty and bilateral kyphoplasty are safe and effective treatments for OVCFs. However, when operative time, cement volume, cement leakage, short-term general health, radiation dose, and hospitalization costs are taken into consideration, unilateral kyphoplasty may be the better choice. Yet, more high-quality RCTs with long-term follow-up are still required to make the final conclusion.

Key words: Kyphoplasty, unilateral approach, bilateral approach, osteoporotic vertebral compression fractures, meta-analysis

Pain Physician 2016; 19:551-563 
$\mathrm{n}$ recent years, osteoporotic fractures have attracted more and more attention around the world. Type of metabolic bone disease is usually caused by a low level of bone mass and primary resorption of horizontal trabecula which increases the risk of fracture (1). Lower thoracic and lumbar vertebrae are the most common occurring sites of osteoporotic vertebral compression fractures (OVCFs) in the spine (2). It is reported that approximately $8 \%$ of women over 50 years old and $27 \%$ of women over 80 years old suffer from OVCFs (3). After diagnosis, patients are primarily treated conservatively with bed rest, braces, analgesics, and physical therapy. Although 2/3 of these patients improve (4), those who still suffer from pain after 4 weeks of conservative therapy, should consider vertebroplasty or kyphoplasty.

Percutaneous vertebroplasty (PVP) and percutaneous balloon kyphoplasty (PKP) are both forms of widely used, minimally invasive spine surgical techniques. Both share similar effectiveness in pain relief. Although PKP is superior in reducing the cement leakage rate and kyphotic angle, it requires a longer operational time and has a higher performance cost (5-9). Traditionally PKP was performed with a bipedicular approach using 2 balloon tamps (10). Recently, a unipedicular, single balloon tamp technique has become popular. This technique is thought to be comparable to the bipedicular approach in its ability to recover vertebral body strength and stiffness (11). A unipedicular approach however, requires less operating room time and requires less cement volume (12).

Several meta-analyses have evaluated clinical outcomes of the 2 kyphoplasty techniques (13-15). However, these studies include relatively small sample sizes and some methodological and statistical errors. What's more, a new randomized controlled trial (RCT) with 309 patients was published in 2014 (4), the sample size of which was almost equivalent to the total number of patients in RCTs published before. Some important information may be provided if this study is enrolled into analysis. So we consider that it is necessary to conduct a new metaanalysis over these studies to make a relatively more credible and overall assessment about unilateral kyphoplasty versus bilateral kyphoplasty in treating OVCFs.

\section{Methods}

\section{Search Strategy and Study Selection}

We followed the Preferred Reporting Items for Systematic Reviews and Meta-Analyses (PRISMA) reporting guidelines (16) and the recommendations of Cochrane
Collaboration (17) to carry out this meta-analysis. The PubMed MEDLINE, Cochrane Library, Web of Science, and EMBASE were searched for RCTs published up to June 2015. Key terms used for database research were unilateral, unipedicular, bilateral, bipedicular, and kyphoplasty. The references of full-text articles were also searched manually to avoid omitted studies. The restriction of publication language was selected as English.

Studies were included if the study was a RCT focusing on comparing unilateral versus bilateral balloon kyphoplasty in treatment of OVCFs. One of the following results should have been reported: operative time, cement volume, visual analog scale (VAS) score, Oswestry Disability Index (ODI) score, kyphotic angle reduction, restoration rate of anterior vertebral height, vertebral height loss rate, cement leakage, postoperative adjacent-level fractures, or 36-Item Short Form Health Survey (SF-36) subscale scores. The exclusion criteria contained infection, neoplastic etiology, traumatic fracture, neural compression, neurological deficit, spinal stenosis, previous surgery at the involved vertebral body, long-term use of steroids, and PKP with other invasive or semi-invasive interventional treatment(s). Retrospective studies, reviews, technology introductions, and biochemical trials were also excluded.

Title and abstract related to the eligibility criteria were screened independently by 2 reviewers (H.S. and P.L.). Full text of the primarily screened literature was read to make the final inclusion. All reviewers followed the unified search strategy. Disagreements were resolved by discussion.

\section{Data Extraction}

Data extraction was performed by 2 authors (H.S. and P.L.). Relevant data included patient characteristics (e.g., age, gender), duration of follow-up, intervention, and outcomes. The primary outcome measures were VAS score, cement leakage, postoperative adjacentlevel fractures, restoration rate of anterior vertebral height, and kyphotic angle reduction, while secondary outcomes included operative time, cement volume, ODI score, vertebral height loss rate, and SF-36 subscale scores. Short-term follow-up was defined as within 4 weeks, mid-term follow-up was defined as 4 weeks to 6 months, and long-term was defined as more than 6 months. We extracted data from graphs or calculated data with the guidance of the Cochrane Handbook for Systematic Reviews of Interventions 5.1.0 (18) when the conventional formats of data were not available in the articles. Discrepancies about data extraction were resolved by discussion among the first 3 authors. 


\section{Data Analysis}

All the meta-analyses were performed by Review Manager Software (RevMan Version 5.3, The Cochrane Collaboration, Copenhagen, Denmark). Mean difference (MD) and $95 \%$ confidence intervals (CI) were used to assess continuous outcomes while risk ratios (RR) were used for dichotomous outcomes. The level of significance was set at $P<0.05$. It was also considered as statistically significant if ' 0 ' were not included in the $95 \% \mathrm{Cl}$ of $\mathrm{MD}$ or ' 1 ' were not included in the $95 \% \mathrm{Cl}$ of RR. The Q test and $I^{2}$ statistic were used to evaluate heterogeneity. If $P>0.1$ and $\mathrm{I}^{2}<50 \%$, which indicated homogeneity, then a fixed effect model was used. However, a random effects model was used when $P \leq 0.1$ or $I^{2} \geq 50 \%$. The source of heterogeneity was investigated by a sensitivity analysis. Some parameters such as radiation dose and hospitalization costs were only reported in a single study so that they were unsuitable for metaanalysis and we will discuss them later in this text.

\section{Assessment of Methodological Quality and Evidence Synthesis}

Two authors (H.S. and P.L.) independently assessed the risk of bias of the included studies based on the Cochrane Handbook for Systematic Reviews of Interven- tions 5.1.0 (18) with the application of the "Cochrane collaboration's tool for assessing the risk of bias." Evidence grade of outcome was evaluated in accordance with the Grading of Recommendations Assessment, Development, and Evaluation (GRADE) (19). Any disagreement was resolved by discussing with a third reviewer (Y.L.).

\section{Results}

\section{Search Results}

A total of 234 titles and abstracts were found through the primary search. After excluding duplicate and irrelevant studies, 38 studies were assessed for eligibility and the full text read. Among them, the following 32 articles were excluded: 9 biomechanical studies (11,20-27), 5 technology-introductive articles (28-32), 5 review articles $(13-15,33,34), 2$ retrospective studies $(12,35), 8$ studies that did not include comparison between unilateral approach and bilateral approach $(2,36-42)$, and 3 articles in which the injuries were not osteoporotic vertebral compression fracture (43-45). Of the 38 studies, only 6 studies were included in our meta-analysis (4,46-50) (Fig. 1).

A total of 562 patients (289 unilateral kyphoplasty

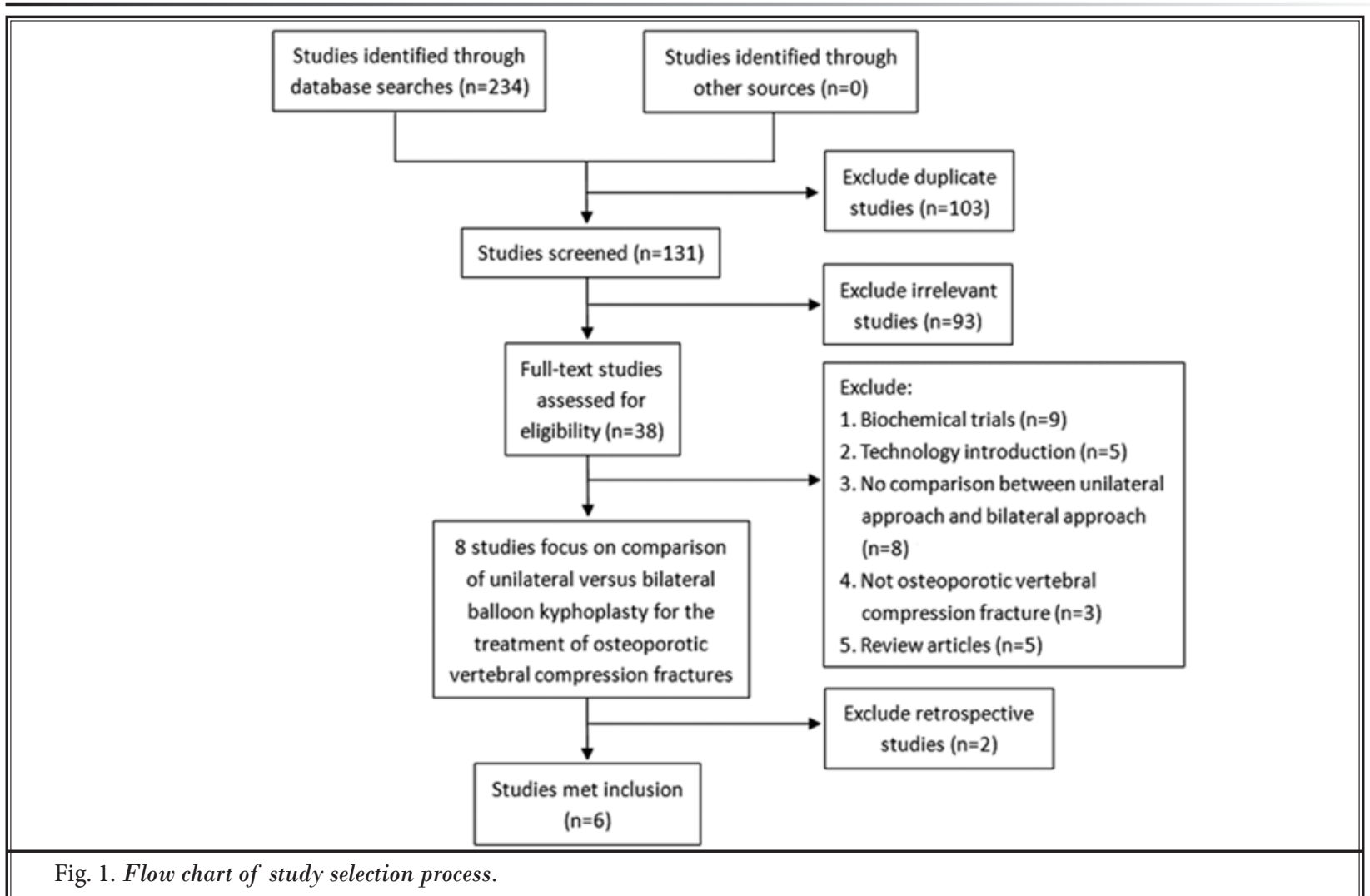




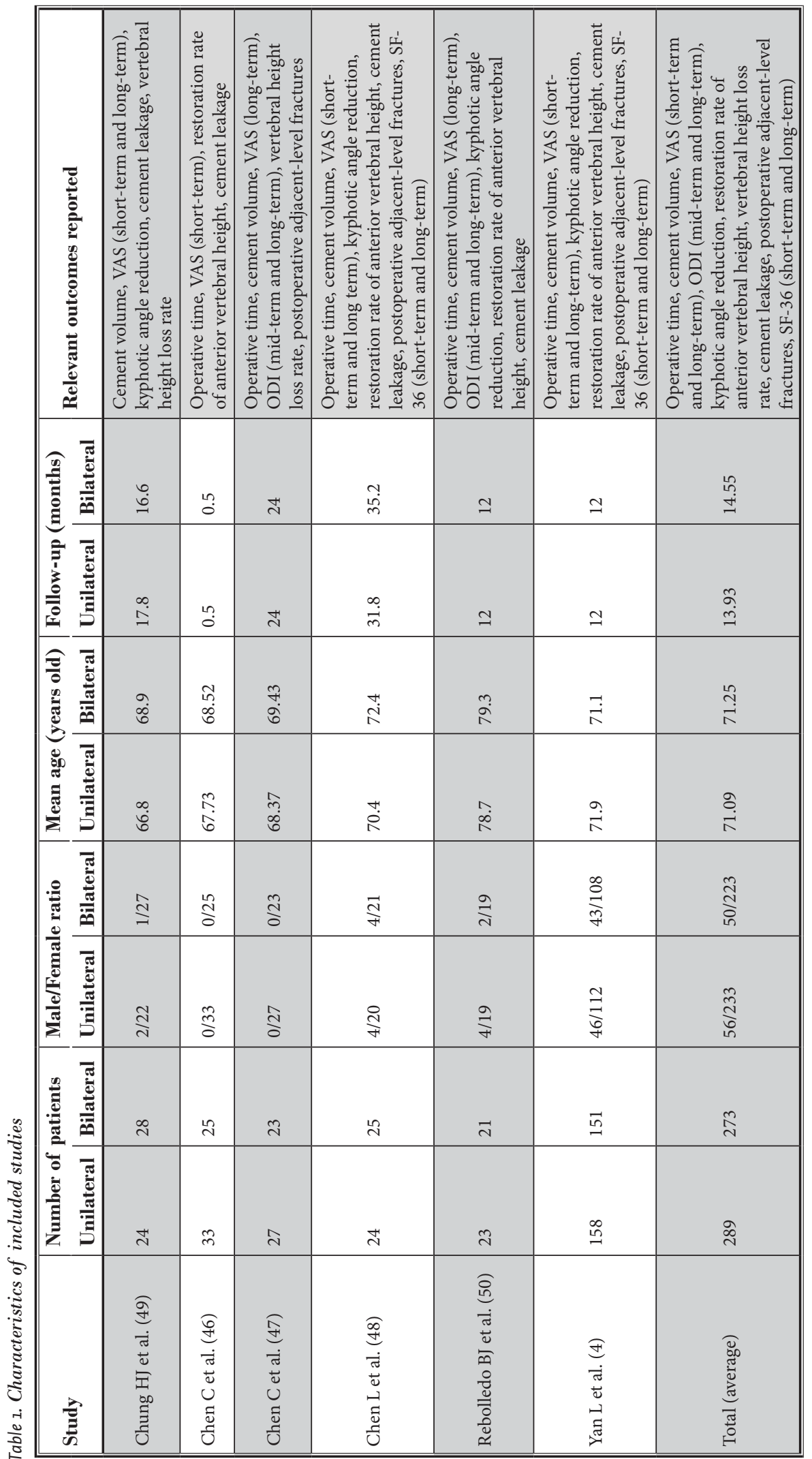

and 273 bilateral kyphoplasty) with mean age of 71.16 years old were enrolled in this meta-analysis. Among them, 106 were men and 456 were women. The mean follow-up was 14.24 months. Detailed characteristics of included studies are summarized (Table 1). Preoperative clinical data ( $T$ value and VAS score) of 2 the groups revealed no significant difference (Table 2).

\section{Quality Assessment}

Assessment of risk bias in the 6 studies is shown in Fig. 2. All of these studies were described as being randomized. Only one study (4) described an adequate sequence generation. None of the included studies reported allocation concealment, blinding of performance, or outcome assessors. The study of Rebolledo et al (50) contained a high rate of lost to follow-up and thus possessed a high risk of attrition bias.

\section{Operative Time and Cement Volume}

Details of intraoperative measurements have been summarized (Table 2). Five studies reported operative time $(4,46-48,50)$, and the pooled result indicated that unilateral kyphoplasty possessed shorter operative times (MD, $-23.19 ; 95 \% \mathrm{Cl}$, $[-27.08,-19.31] ; P<0.00001 ; I^{2}$ $=77 \%$, random effect model was used) (Fig. 3). The sensitivity analysis showed that the trial reported by Yan et al (4) contributed to the heterogeneity. After rejecting their 


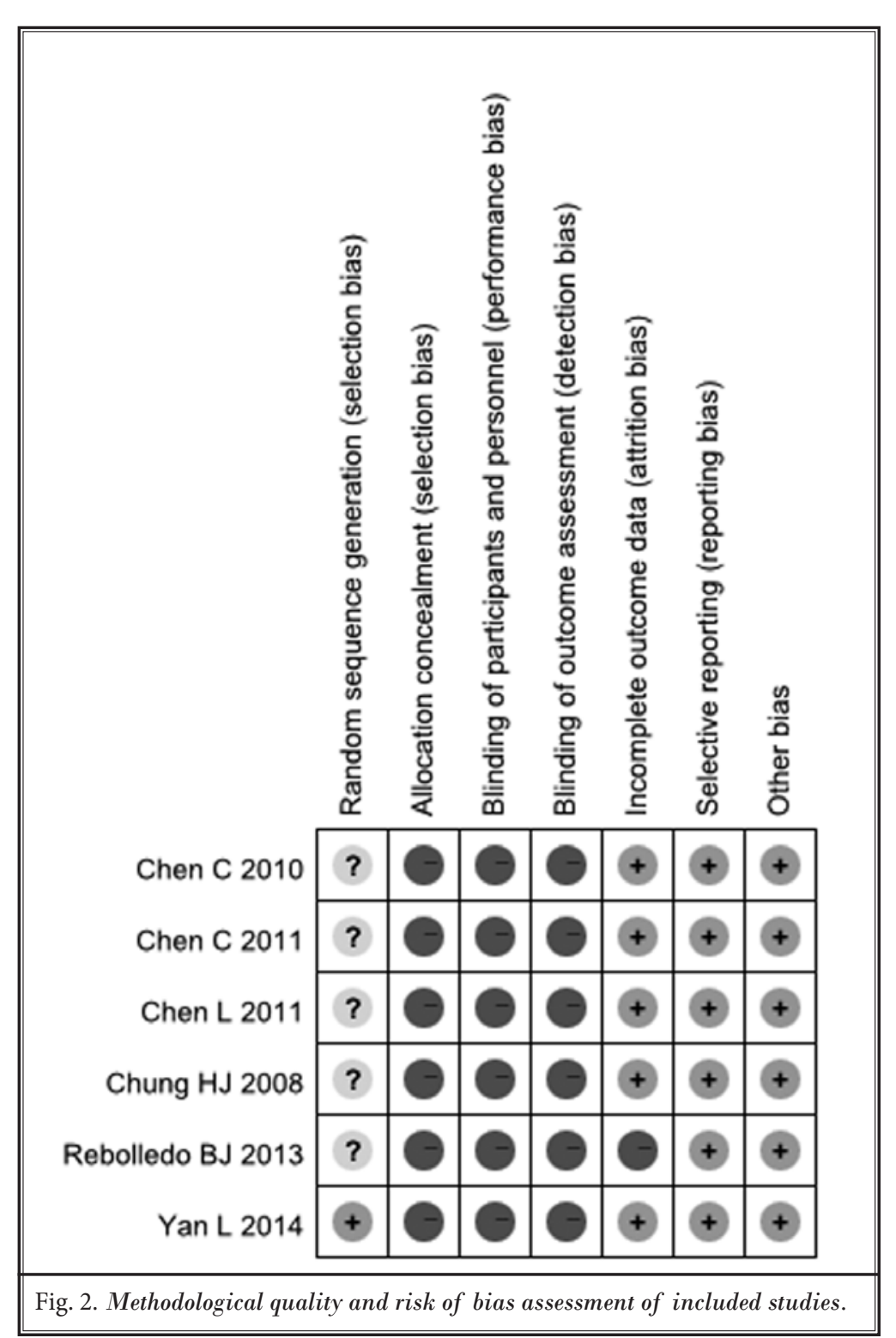

study, no significant difference was found. Cement consumption in the unilateral approach was less than that in the bilateral approach (MD, $-2.07 ; 95 \% \mathrm{Cl},[-2.23,-1.91] ; P<0.00001)$ according to the analysis of 5 studies $(4,47-50)$ (Fig. 4).

\section{Short-term and Long-term VAS Scores}

Unilateral groups and bilateral groups revealed little difference in VAS scores at short-term follow-up in 4 studies $(\mathrm{MD},-0.12 ; 95 \% \mathrm{Cl}$, $[-0.33,0.09] ; P=0.28 ; I^{2}=55 \%$, random effect model was used) (Fig. 5) $(4,46,48,49)$. Sensitivity analysis revealed that the heterogeneity could be attributed to the study of Chung et al (49), and no difference was found when this study was rejected. Long-term analysis of 5 studies $(4,47-50)$

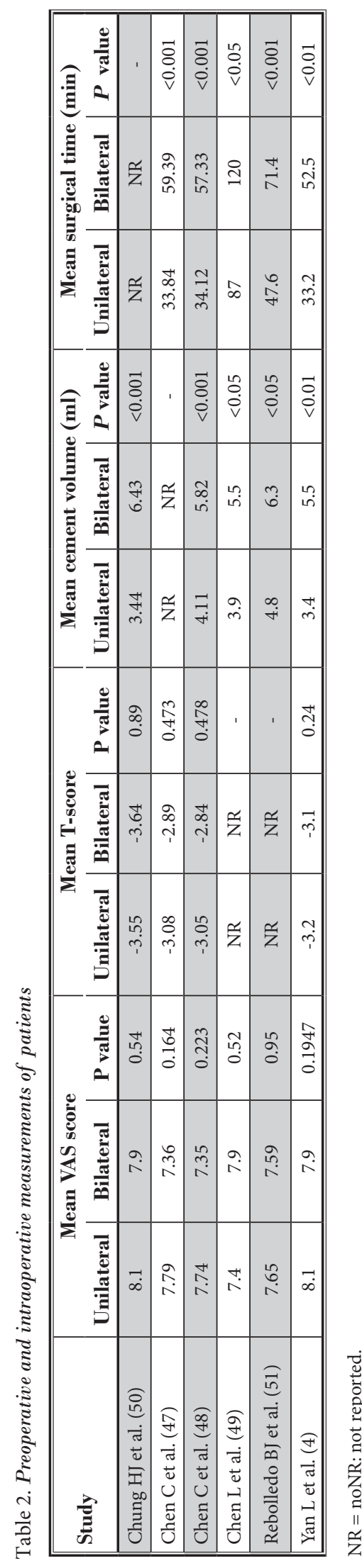




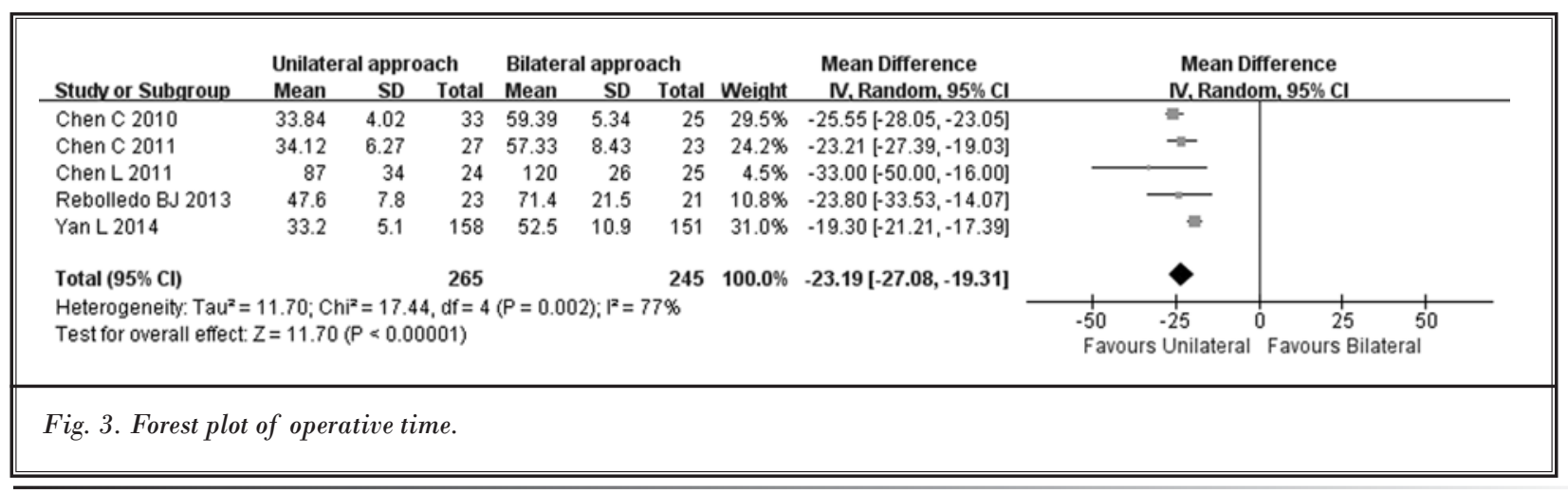

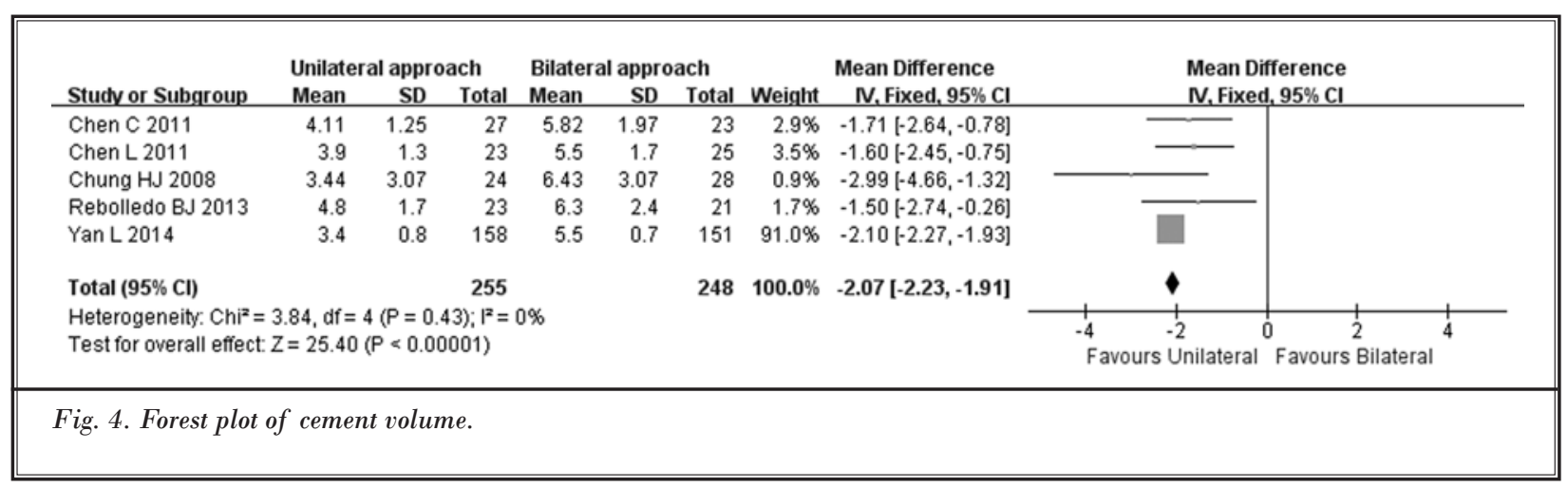

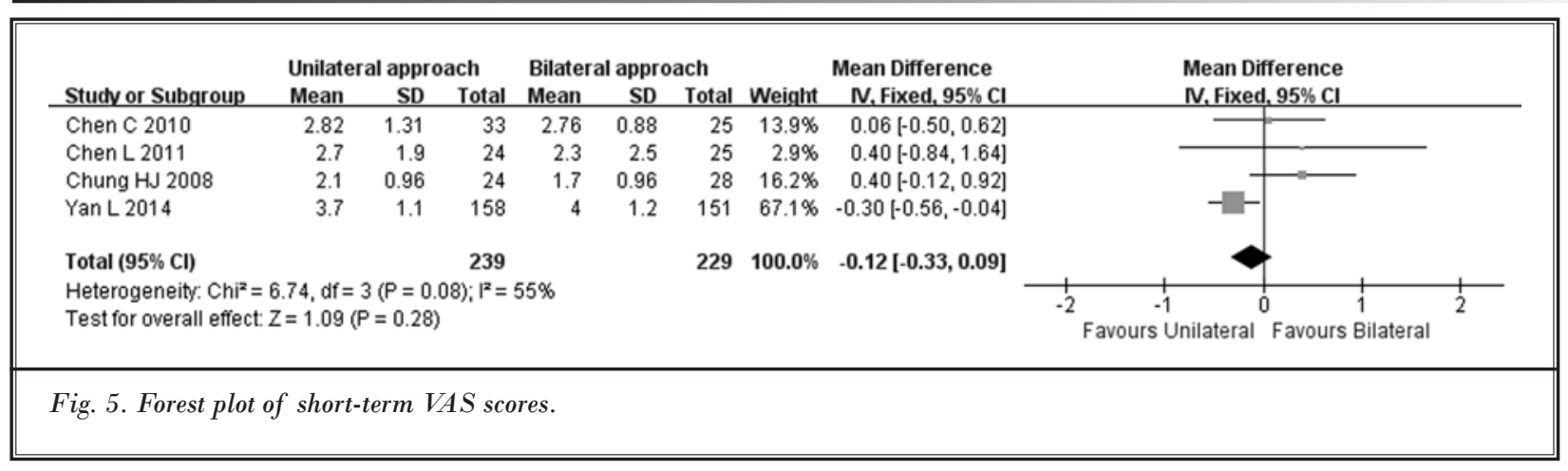

show a similar result (MD, $-0.05 ; 95 \% \mathrm{Cl},[-0.23,0.14], P$ $=0.62$ ) (Fig. 6).

\section{Mid-term and Long-term ODI Scores}

Two studies reported mid-term ODI scores $(47,50)$. Results of analysis revealed that there was no significant difference between the unilateral approach and the bilateral approach (MD, $-1.68 ; 95 \% \mathrm{Cl},[-3.90,0.55]$; $P=0.14$ ) (Fig. 7). The pooled result from long-term follow-up from 2 studies present similar results $(47,50)$ (MD, $-0.88 ; 95 \% \mathrm{Cl},[-3.55,1.80] ; P=0.52$ ) (Fig. 8).

\section{Radiographic Assessments}

Both the postoperative kyphosis angle reduction and the restoration rate of anterior vertebral height have been analyzed. Four studies reported postoperative kyphosis angle reduction (4,48-50), and the analysis revealed no statistic difference between the 2 groups (MD, $-0.24 ; 95 \% \mathrm{Cl},[-4.51,4.02] ; P=0.91 ; \mathrm{I}^{2}=93 \%$, random effect model was used). Sensitivity analysis showed that the statistical result could not be materially altered by eliminating any study. When it came to the restoration rate of anterior vertebral height data, 
Unilateral Kyphoplasty for Osteoporotic Vertebral Compression Fractures

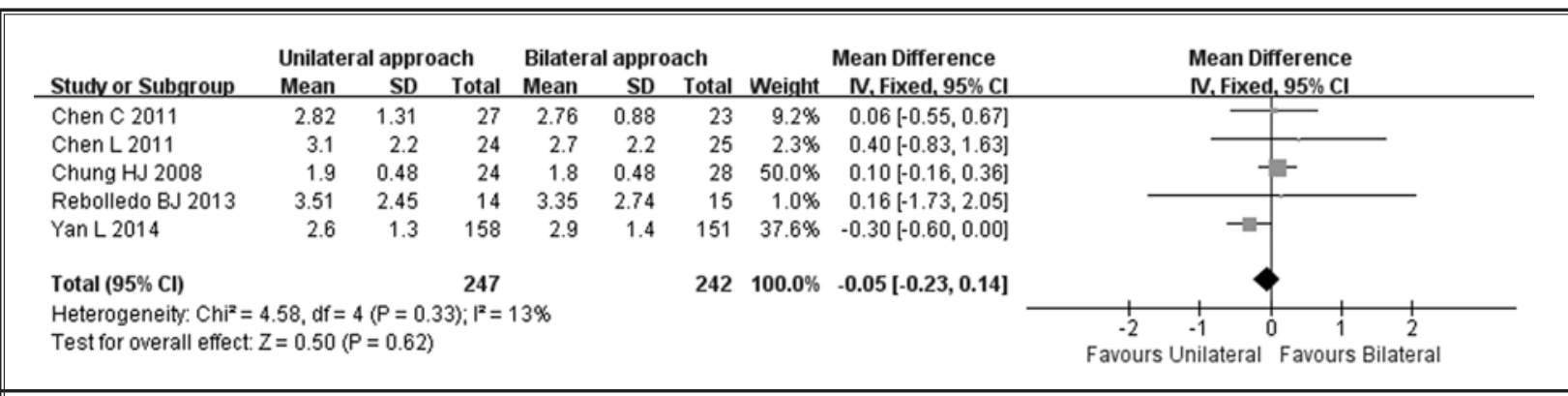

Fig. 6. Forest plot of long-term VAS scores.

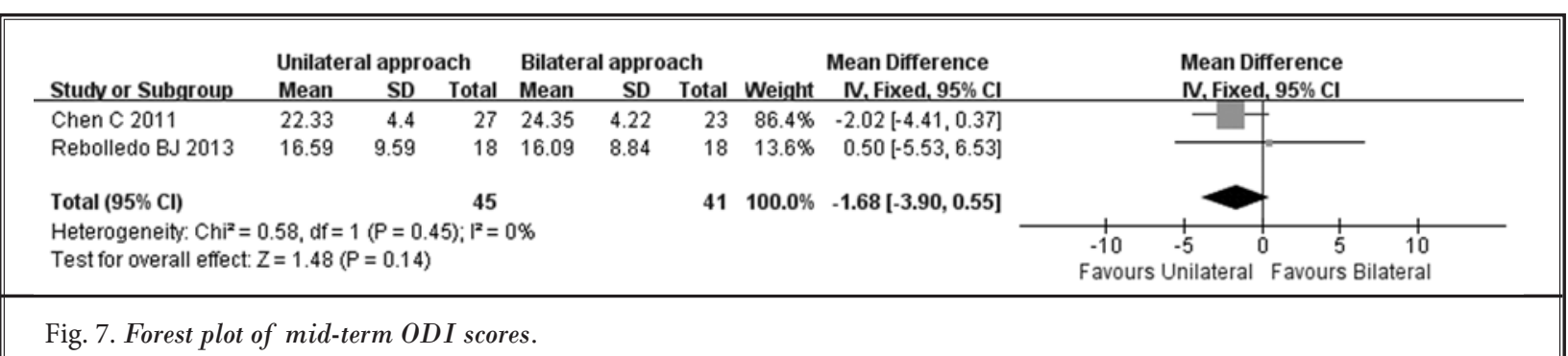

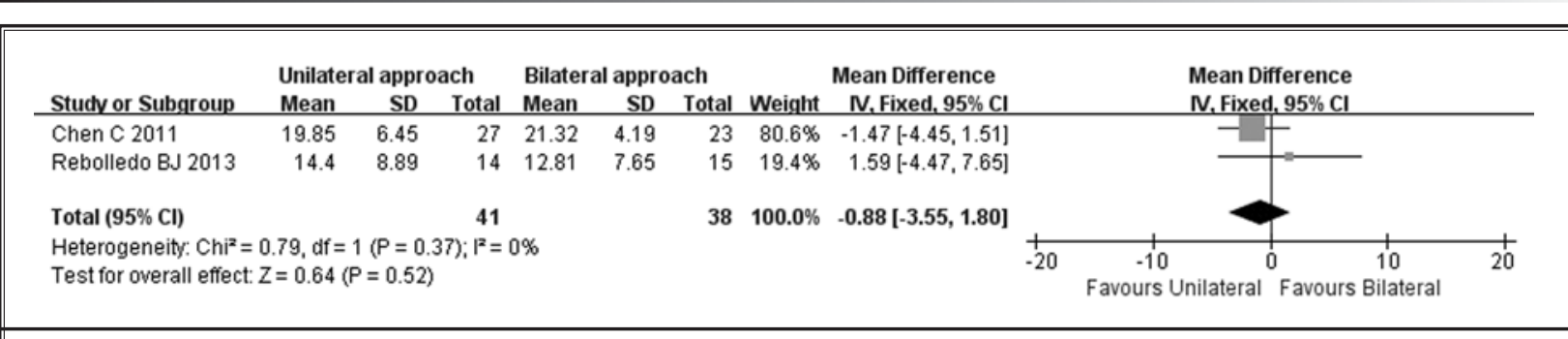

Fig. 8. Forest plot of long-term ODI scores.

which were available in 4 studies $(4,46,48,50)$, there was also little difference between unilateral and bilateral kyphoplasty (MD, 2.35; 95\% Cl, $[-6.65,11.35] ; P=0.61$; $\mathrm{I}^{2}=88 \%$, random effect model was used). Sensitivity analysis exhibited that the study of Chen et al (46) was the main cause of heterogeneity. The two kinds of kyphoplasty were also comparable in vertebral height loss rate which was reported by Chen (47) and Chung et al (49) (MD, 2.08; 95\% Cl, [-0.39, 4.54], $P=0.10 ; I^{2}=$ $68 \%$, random effect model was used) (Table 3 ). As only 2 studies were included, the sensitivity analysis could not be conducted.

\subsection{Postoperative Complications}

Cement leakage and adjacent-level fractures were the 2 major kinds of postoperative complications reported in these studies. Among them, analysis of cement leakage during long-term follow-up reported in 5 out of the 6 studies $(4,46,48-50)$ demonstrated that the unilateral approach possessed a relatively low leakage ratio (RR, 0.59; 95\% Cl, [0.35, 0.99]; $P<0.05$ ) (Fig. 9). Three studies with a total of 416 patients were followed up for postoperative adjacent-level fractures $(4,47,48)$. Results showed no statistical difference between the 2 approaches (RR, 0.80; 95\% Cl, [0.32, 2.00]; $P=0.63$ ) (Fig. 10).

\subsection{SF-36 Subscale Scores}

Two studies used the SF-36 subscale scores to assess the quality of life $(4,48)$. A total of 8 dimensionality concepts were incorporated into the analysis, including physical function (PF), role limitations due to physical health (RP), bodily pain (BP), general health $(G H)$, vitality (VT), social function (SF), role limitations due to emotional problems (RE), and mental health $(\mathrm{MH})$. The 
Table 3. Results of radiographic assessment

\begin{tabular}{|l|c|c|c|c|c|c||}
\hline \multirow{2}{*}{ Assessment items } & \multirow{2}{*}{$\begin{array}{c}\text { Number of } \\
\text { included studies }\end{array}$} & \multicolumn{2}{|c|}{ Number of patients } & \multirow{2}{*}{ MD } & \multirow{2}{*}{ 95\% CI } & \multirow{2}{*}{$\boldsymbol{P}$ value } \\
& Unilateral & bilateral & & & & \\
\hline Kyphotic angle reduction & 4 & 229 & 225 & -0.24 & {$[-4.52,4.02]$} & 0.91 \\
\hline Restoration rate of anterior vertebral height & 4 & 238 & 222 & 2.35 & {$[-6.65,11.35]$} & 0.61 \\
\hline Vertebral height loss rate & 2 & 51 & 51 & 2.08 & {$[-0.39,4.54]$} & 0.10 \\
\hline
\end{tabular}

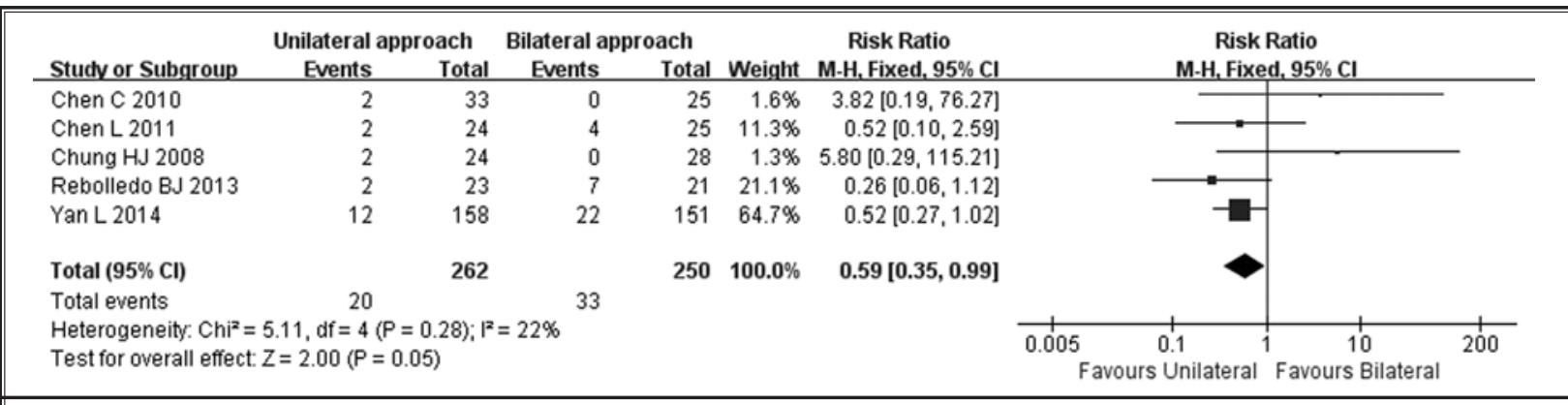

Fig. 9. Forest plot of cement leakage.

\begin{tabular}{|c|c|c|c|c|c|c|c|c|c|c|}
\hline \multirow[b]{2}{*}{ Studv or Subgroup } & \multicolumn{2}{|c|}{ Unilateral approach } & \multicolumn{2}{|c|}{ Bilateral approach } & \multirow{2}{*}{ Weight } & \multirow{2}{*}{$\begin{array}{c}\text { Risk Ratio } \\
\text { M.H. Fixed, } 95 \% \mathrm{Cl}\end{array}$} & \multirow{2}{*}{\multicolumn{4}{|c|}{$\begin{array}{c}\text { Risk Ratio } \\
\text { M-H. Fixed, 95\% Cl }\end{array}$}} \\
\hline & Events & Total & Events & Total & & & & & & \\
\hline Chen C 2011 & 4 & 33 & 2 & 25 & $23.1 \%$ & $1.52[0.30,7.62]$ & & & $=$ & \\
\hline Chen L 2011 & 0 & 24 & 2 & 25 & $24.9 \%$ & $0.21[0.01,4.12]$ & & & & \\
\hline Yan L 2014 & 4 & 158 & 5 & 151 & $52.0 \%$ & $0.76[0.21,2.79]$ & & 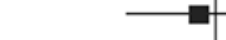 & & \\
\hline Total $(95 \% \mathrm{Cl})$ & & 215 & & 201 & $100.0 \%$ & $0.80[0.32,2.00]$ & & & & \\
\hline Total events & 8 & & 9 & & & & & & & \\
\hline $\begin{array}{l}\text { Heterogeneity. } \mathrm{Chi}^{2}= \\
\text { Test for overall effect: }\end{array}$ & $\begin{array}{l}1.39, d f=2 \\
Z=0.48(P=\end{array}$ & 3) & $=0 \%$ & & & & 0.01 & $\begin{array}{c}0.1 \\
\text { Favours Unilateral }\end{array}$ & $\begin{array}{c}10 \\
\text { Favours Bilateral }\end{array}$ & 100 \\
\hline
\end{tabular}

Fig. 10. Forest plot of postoperative adjacent-level fractures.

pooled results showed that the unilateral approach was superior in short-term general health (MD, 1.48; $95 \%$ $\mathrm{Cl},[0.02,2.93], P<0.05)$. There were no significant differences between the 2 groups in other assessments of SF-36 parameters (Table 4). The sensitivity analysis of short-term and long-term role on physical health could not be conducted because of the limited number of studies.

\section{Quality of the Evidence and Publication Bias}

We used the GRADE system to assess quality of outcomes in this study. Operative time and cement volume showed high quality of evidence while postoperative adjacent-level fractures revealed moderate quality of evidence. The evidence for long-term VAS score, shortterm and long-term ODI scores, and cement leakage was low. When assessing the results of short-term VAS score, kyphotic angle reduction, restoration rate of anterior vertebral height, and vertebral height loss rate, the evidence was very low. As to SF-36, the evidence was low for each result except for short-term and longterm role physical, the qualities of which were further downgraded to very low because of the inconsistent results (Table 5 ).

The publication bias and funnel plots were not reliable due to the limited number of studies (51).

\section{Discussion}

Osteoporosis is mainly caused by the imbalance between bone formation and resorption, which can significantly influence quality of life. The ideal treatment for OVCFs should possess characteristics of minimal invasion, short operative time, and lasting improvement of symptoms and kyphotic deformity (52). Compared 
with PVP, bilateral PKP has similar clinical outcomes but requires a longer operative time and higher hospitalization expenses, which have been proven by many meta-analyses (5-9).

In recent years, unipedicular kyphoplasty has been performed and may improve the aforementioned deficiencies. Chen et al (21) found that unipedicular kyphoplasty could construct biomechanical balance by distributing cement uniformly. With proper needle tip positioning, the cement should cross the midline of the affected vertebra. Results of cadaveric studies have shown that mechanically sufficient structural support can be achieved using a unilateral approach with proper technique and even distribution of the cement (11).

However, when it came to the question of whether unilateral kyphoplasty was as efficient as bilateral kyphoplasty or the question of which technique was better, there seemed to be no definitive answer which lead us to perform this meta-analysis.

A unilateral technique has several operative advantages. Since only one needle is placed and because the puncture point begins in a more lateral position compared to a bilateral approach, risks such as spinal cord injury, pedicle and facet joint fracture, and spinal epidural hematoma are reduced. The results of our study also revealed that compared with a bilateral approach, a unilateral approach significantly decreases operative time and cement usage. These findings were consistent since each of the included studies demonstrated the same results (4,46-50). Accordingly, radiation exposure and costs should also be reduced (38). Yan et al (4) found that the radiation to each patient in the unilateral group was $50 \%$ of the dose received by the bilateral group. It was also estimated that if $5 \%$ of OVCFs were treated by unilateral kyphoplasty instead of bilateral kyphoplasty in the United States, the annual savings would be $\$ 32$ million dollars (11).

Results of pain relief measured by VAS score revealed no significant difference between the 2 groups in either short-term or long-term follow-up. ODI score is another important clinical effectiveness assessment. We extracted the data of ODI score from the graphs in the study of Rebolledo et al (50) for the application of meta-analysis and found that the pooled outcome analysis revealed no statistically significant differences between the 2 approaches regardless of mid- or longterm follow-up.

In radiographic outcomes assessment, kyphotic angle reduction revealed no obviously difference between the unilateral approach and the bilateral

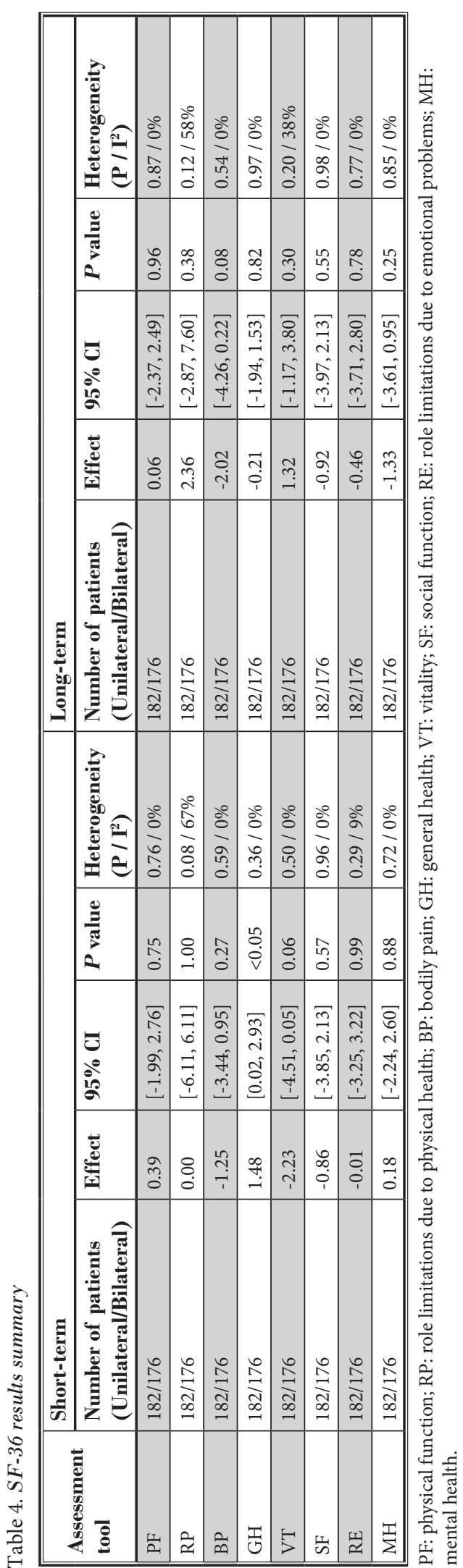


Table 5. Quality of the evidence

\begin{tabular}{|c|c|c|c|c|}
\hline Outcomes & \begin{tabular}{|l|} 
No. of \\
Participants \\
(studies) \\
Follow up \\
\end{tabular} & $\begin{array}{l}\text { Quality of the evidence } \\
\text { (GRADE) }\end{array}$ & $\begin{array}{l}\text { Relative } \\
\text { effect } \\
(95 \% \text { CI })\end{array}$ & $\begin{array}{l}\text { Anticipated absolute } \\
\text { effects }\end{array}$ \\
\hline $\begin{array}{l}\text { Operative time } \\
\text { operation time }\end{array}$ & 510 (5 studies) & $\begin{array}{l}\text { HIGH1,2,3 } \\
\text { due to risk of bias, large effect }\end{array}$ & & $\begin{array}{l}\text { MD 23.19 lower } \\
\text { (27.08 to } 19.31 \text { lower) }\end{array}$ \\
\hline $\begin{array}{l}\text { Cement volume } \\
\text { volume of cement used in surgery }\end{array}$ & 503 (5 studies) & $\begin{array}{l}\text { HIGH1,2,3 } \\
\text { due to risk of bias, large effect }\end{array}$ & & $\begin{array}{l}\text { MD 2.07 lower } \\
\text { (2.23 to } 1.91 \text { lower) }\end{array}$ \\
\hline $\begin{array}{l}\text { Short-term VAS score } \\
\text { VAS. Scale from: } 1 \text { to } 10\end{array}$ & $\begin{array}{l}468 \text { ( } 4 \text { studies) } \\
2 \text { - } 4 \text { weeks }\end{array}$ & $\begin{array}{l}\text { VERY LOW } 1,2,4,5 \\
\text { due to risk of bias, inconsistency, } \\
\text { imprecision }\end{array}$ & & $\begin{array}{l}\text { MD } 0.12 \text { lower } \\
(0.33 \text { lower to } 0.09 \text { higher })\end{array}$ \\
\hline $\begin{array}{l}\text { Long-term VAS score } \\
\text { VAS. Scale from: } 1 \text { to } 10\end{array}$ & $\begin{array}{l}489 \text { ( } 5 \text { studies) } \\
12-35.2 \text { months }\end{array}$ & $\begin{array}{l}\text { LOW } 1,2,5 \\
\text { due to risk of bias, imprecision }\end{array}$ & & $\begin{array}{l}\text { MD } 0.05 \text { lower } \\
(0.23 \text { lower to } 0.14 \text { higher })\end{array}$ \\
\hline $\begin{array}{l}\text { Kyphotic angle reduction } \\
\text { postoperative kyphotic angle } \\
\text { reduction. Scale from: } 1 \text { to } 180\end{array}$ & $\begin{array}{l}441 \text { ( } 4 \text { studies) } \\
0-12 \text { months }\end{array}$ & $\begin{array}{l}\text { VERY LOW } 1,2,4,5,6 \\
\text { due to risk of bias, inconsistency, } \\
\text { imprecision }\end{array}$ & & $\begin{array}{l}\text { MD } 0.24 \text { lower } \\
\text { (4.51 lower to } 4.02 \text { higher) }\end{array}$ \\
\hline $\begin{array}{l}\text { Restoration rate of anterior height } \\
\text { postoprative restoration rate of } \\
\text { anterior height. Scale from: } 0 \text { to } \\
100 \%\end{array}$ & $\begin{array}{l}447 \text { ( } 3 \text { studies) } \\
0-12 \text { months }\end{array}$ & $\begin{array}{l}\text { VERY LOW } 1,2,4,5,6 \\
\text { due to risk of bias, inconsistency, } \\
\text { imprecision }\end{array}$ & & $\begin{array}{l}\text { MD } 2.35 \text { higher } \\
\text { ( } 6.65 \text { lower to } 11.35 \text { higher) }\end{array}$ \\
\hline $\begin{array}{l}\text { Vertebral height loss rate } \\
\text { (each time point vertebral height - } \\
\text { restored vertebral height) / restored } \\
\text { vertebral height }\end{array}$ & 102 (2 studies) & $\begin{array}{l}\text { VERY LOW } 1,2,4,7 \\
\text { due to risk of bias, inconsistency, } \\
\text { imprecision }\end{array}$ & & $\begin{array}{l}\text { MD } 2.08 \text { higher } \\
\text { ( } 0.39 \text { lower to } 4.54 \text { higher })\end{array}$ \\
\hline $\begin{array}{l}\text { Mid-term ODI score } \\
\text { ODI. Scale from: } 0 \text { to } 50\end{array}$ & $\begin{array}{l}86 \text { ( } 2 \text { studies }) \\
3 \text { - } 6 \text { months }\end{array}$ & $\begin{array}{l}\text { LOW } 1,2,7 \\
\text { due to risk of bias, imprecision }\end{array}$ & & $\begin{array}{l}\text { MD } 1.68 \text { lower } \\
\text { (3.90 lower to } 0.55 \text { higher) }\end{array}$ \\
\hline $\begin{array}{l}\text { Long-term ODI score } \\
\text { ODI. Scale from: } 0 \text { to } 50\end{array}$ & \begin{tabular}{|l|}
79 (2 studies) \\
$12-24$ months
\end{tabular} & $\begin{array}{l}\text { LOW } 1,2,7 \\
\text { due to risk of bias, imprecision }\end{array}$ & & $\begin{array}{l}\text { MD } 0.88 \text { lower } \\
\text { (3.35 lower to } 1.80 \text { higher) }\end{array}$ \\
\hline $\begin{array}{l}\text { Cement leakage } \\
\text { X-ray }\end{array}$ & $\begin{array}{l}512 \text { ( } 5 \text { studies) } \\
12-35.2 \text { months }\end{array}$ & $\begin{array}{l}\text { LOW } 1,2,4 \\
\text { due to risk of bias, inconsistency }\end{array}$ & $\begin{array}{l}\text { RR } 0.59 \\
(0.35 \text { to } \\
0.99)\end{array}$ & $\begin{array}{l}54 \text { fewer per } 1000 \\
\text { (from } 1 \text { fewer to } 86 \text { fewer) }\end{array}$ \\
\hline $\begin{array}{l}\text { Postoperative adjacent-level } \\
\text { fractures } \\
\text { X-ray }\end{array}$ & $\begin{array}{l}416 \text { ( } 3 \text { studies) } \\
12-35.2 \text { months }\end{array}$ & $\begin{array}{l}\text { MODERATE1,2 } \\
\text { due to risk of bias }\end{array}$ & $\begin{array}{l}\text { RR } 0.80 \\
\text { (0.32 to } 2)\end{array}$ & $\begin{array}{l}9 \text { fewer per } 1000 \\
\text { (from } 30 \text { fewer to } 45 \text { more) }\end{array}$ \\
\hline $\begin{array}{l}\text { Short-term PF } \\
\text { Short-term physical function }\end{array}$ & $\begin{array}{l}358 \text { ( } 2 \text { studies }) \\
0-1 \text { months }\end{array}$ & $\begin{array}{l}\text { LOW } 1,2,7 \\
\text { due to risk of bias, imprecision }\end{array}$ & & $\begin{array}{l}\text { MD 0.39 higher } \\
\text { (1.99 lower to } 2.76 \text { higher) }\end{array}$ \\
\hline $\begin{array}{l}\text { Long-term RF } \\
\text { Long-term physical function }\end{array}$ & $\begin{array}{l}358 \text { ( } 2 \text { studies) } \\
12-35.2 \text { months }\end{array}$ & $\begin{array}{l}\text { LOW } 1,2,7 \\
\text { due to risk of bias, imprecision }\end{array}$ & & $\begin{array}{l}\text { MD } 0.06 \text { higher } \\
\text { (2.37 lower to } 2.49 \text { higher) }\end{array}$ \\
\hline $\begin{array}{l}\text { Short-term RP } \\
\text { Short-term role physical }\end{array}$ & $\begin{array}{l}358 \text { (2 studies) } \\
0-1 \text { months }\end{array}$ & $\begin{array}{l}\text { VERY LOW } 1,2,4,7 \\
\text { due to risk of bias, inconsistency, } \\
\text { imprecision }\end{array}$ & & $\begin{array}{l}\text { MD } 0.00 \\
\text { (6.11 lower to } 6.11 \text { higher) }\end{array}$ \\
\hline $\begin{array}{l}\text { Long-term RP } \\
\text { Long-term role physical }\end{array}$ & $\begin{array}{l}358 \text { ( } 2 \text { studies) } \\
12-35.2 \text { months }\end{array}$ & $\begin{array}{l}\text { VERY LOW } 1,2,4,7 \\
\text { due to risk of bias, inconsistency, } \\
\text { imprecision }\end{array}$ & & $\begin{array}{l}\text { MD } 2.36 \text { higher } \\
\text { ( } 2.87 \text { lower to } 7.60 \text { higher) }\end{array}$ \\
\hline $\begin{array}{l}\text { Short-term BP } \\
\text { Short-term bodily pain }\end{array}$ & $\begin{array}{l}358 \text { (2 studies) } \\
0-1 \text { months }\end{array}$ & $\begin{array}{l}\text { LOW } 1,2,7 \\
\text { due to risk of bias, imprecision }\end{array}$ & & $\begin{array}{l}\text { MD } 1.25 \text { lower } \\
\text { (3.44 lower to } 0.95 \text { higher) }\end{array}$ \\
\hline $\begin{array}{l}\text { Long-term BP } \\
\text { Long-term bodily pain }\end{array}$ & $\begin{array}{l}358 \text { ( } 2 \text { studies) } \\
12-35.2 \text { months }\end{array}$ & $\begin{array}{l}\text { LOW } 1,2,7 \\
\text { due to risk of bias, imprecision }\end{array}$ & & $\begin{array}{l}\text { MD } 2.02 \text { lower } \\
\text { ( } 4.26 \text { lower to } 0.22 \text { higher) }\end{array}$ \\
\hline $\begin{array}{l}\text { Short-term GH } \\
\text { Short-term general health }\end{array}$ & $\begin{array}{l}358 \text { ( } 2 \text { studies }) \\
0-1 \text { months }\end{array}$ & $\begin{array}{l}\text { LOW } 1,2,7 \\
\text { due to risk of bias, imprecision }\end{array}$ & & $\begin{array}{l}\text { MD } 1.48 \text { higher } \\
\text { (0.02 higher to } 2.93 \text { higher) }\end{array}$ \\
\hline $\begin{array}{l}\text { Long-term GH } \\
\text { Long-term general health }\end{array}$ & $\begin{array}{l}358 \text { ( } 2 \text { studies) } \\
12-35.2 \text { months }\end{array}$ & $\begin{array}{l}\text { LOW } 1,2,7 \\
\text { due to risk of bias, imprecision }\end{array}$ & & $\begin{array}{l}\text { MD } 0.21 \text { lower } \\
\text { (1.94 lower to } 1.53 \text { higher) }\end{array}$ \\
\hline $\begin{array}{l}\text { Short-term VT } \\
\text { Short-term vitality }\end{array}$ & $\begin{array}{l}358 \text { ( } 2 \text { studies }) \\
0-1 \text { months }\end{array}$ & $\begin{array}{l}\text { LOW } 1,2,7 \\
\text { due to risk of bias, imprecision }\end{array}$ & & $\begin{array}{l}\text { MD } 2.23 \text { lower } \\
\text { (4.51 lower to } 0.05 \text { higher) }\end{array}$ \\
\hline
\end{tabular}


Table 5 (cont.). Quality of the evidence

\begin{tabular}{|c|c|c|c|c|}
\hline Outcomes & $\begin{array}{l}\text { No. of } \\
\text { Participants } \\
\text { (studies) } \\
\text { Follow up }\end{array}$ & $\begin{array}{l}\text { Quality of the evidence } \\
\text { (GRADE) }\end{array}$ & $\begin{array}{l}\text { Relative } \\
\text { effect } \\
(95 \% \text { CI })\end{array}$ & $\begin{array}{l}\text { Anticipated absolute } \\
\text { effects }\end{array}$ \\
\hline $\begin{array}{l}\text { Long-term VT } \\
\text { Long-term vitality } \\
\end{array}$ & $\begin{array}{l}358 \text { ( } 2 \text { studies }) \\
12-35.2 \text { months }\end{array}$ & $\begin{array}{l}\text { LOW } 1,2,7 \\
\text { due to risk of bias, imprecision }\end{array}$ & & \begin{tabular}{|l} 
MD 1.32 higher \\
(1.17 lower to 3.80 higher $)$ \\
\end{tabular} \\
\hline $\begin{array}{l}\text { Short-term SF } \\
\text { Short-term social function }\end{array}$ & $\begin{array}{l}358 \text { ( } 2 \text { studies }) \\
0-1 \text { months }\end{array}$ & $\begin{array}{l}\text { LOW } 1,2,7 \\
\text { due to risk of bias, imprecision }\end{array}$ & & $\begin{array}{l}\text { MD } 0.86 \text { lower } \\
\text { (3.85 lower to } 2.13 \text { higher) }\end{array}$ \\
\hline $\begin{array}{l}\text { Long-term SF } \\
\text { Long-term social function }\end{array}$ & $\begin{array}{l}358 \text { ( } 2 \text { studies }) \\
12-35.2 \text { months }\end{array}$ & $\begin{array}{l}\text { LOW } 1,2,7 \\
\text { due to risk of bias, imprecision }\end{array}$ & & $\begin{array}{l}\text { MD } 0.92 \text { lower } \\
\text { (3.97 lower to } 2.13 \text { higher) }\end{array}$ \\
\hline $\begin{array}{l}\text { Short-term RE } \\
\text { Short-term role emotional }\end{array}$ & $\begin{array}{l}358 \text { ( } 2 \text { studies }) \\
0-1 \text { months }\end{array}$ & $\begin{array}{l}\text { LOW } 1,2,7 \\
\text { due to risk of bias, imprecision }\end{array}$ & & $\begin{array}{l}\text { MD } 0.01 \text { lower } \\
\text { (3.25 lower to } 3.22 \text { higher) }\end{array}$ \\
\hline $\begin{array}{l}\text { Long-term RE } \\
\text { Long-term role emotional } \\
\end{array}$ & $\begin{array}{l}358 \text { ( } 2 \text { studies }) \\
12-35.2 \text { months }\end{array}$ & $\begin{array}{l}\text { LOW } 1,2,7 \\
\text { due to risk of bias, imprecision }\end{array}$ & & \begin{tabular}{|l} 
MD 0.46 lower \\
(3.71 lower to 2.80 higher) \\
\end{tabular} \\
\hline $\begin{array}{l}\text { Short-term MH } \\
\text { Short-term mental health }\end{array}$ & $\begin{array}{l}358 \text { ( } 2 \text { studies }) \\
0-1 \text { months }\end{array}$ & $\begin{array}{l}\text { LOW } 1,2,7 \\
\text { due to risk of bias, imprecision }\end{array}$ & & $\begin{array}{l}\text { MD } 0.18 \text { higher } \\
\text { (2.24 lower to } 2.60 \text { higher) }\end{array}$ \\
\hline $\begin{array}{l}\text { Long-term MH } \\
\text { Long-term mental health }\end{array}$ & $\begin{array}{l}358 \text { ( } 2 \text { studies }) \\
12-35.2 \text { months }\end{array}$ & $\begin{array}{l}\text { LOW } 1,2,7 \\
\text { due to risk of bias, imprecision }\end{array}$ & & $\begin{array}{l}\text { MD } 1.33 \text { lower } \\
\text { (3.61 lower to } 0.95 \text { higher) }\end{array}$ \\
\hline \multicolumn{5}{|c|}{$\begin{array}{l}1 \text { No details of randomization; } 2 \text { No concealment; } 3 \text { Effect is really stable; } 4 \text { Result is inconsistent; } 5 \text { Indirect data; } 6 \text { Inconsistent follow-up tim } \\
\text { point; } 7 \text { Limited sample size. }\end{array}$} \\
\hline \multicolumn{5}{|c|}{ CI: Confidence interval; RR: Risk ratio; MD: Mean difference. } \\
\hline
\end{tabular}

approach following random effects model analysis. Analysis of restoration rate of the anterior vertebral height shared the same result, which was consistent with outcomes of some in vitro studies $(11,21)$. It should be noted that Yan et al (4) evaluated the aforementioned 2 parameters at 12 months postoperatively rather than in the immediate postoperative period. Their results indicated that kyphotic angle reduction and restoration rate of the anterior vertebral height in the unilateral group was superior to the bilateral group in long-term follow-up. The unipedicular approach was also comparable to the bipedicular approach in vertebral height loss rate.

Postoperative complications are primarily cement leakage and adjacent-level fracture. Our meta-analysis revealed that unilateral kyphoplasty had reduced cement leakage, which differed from the results reported in previous meta-analyses $(13,14,33)$. Our conclusions were the result of a newly included article with a larger sample size that demonstrated a lower rate of cement leakage, and they attributed this result to the more lateral puncture point and the larger extraversion angle of the unilateral technique so that the bone cement was mainly distributed in the anterior and middle of the vertebral body (4). The cause for the findings may also be due to the greater number of punctures and resultant increase in cement usage in the bipedicular group
(15). However, in previous RCTs and meta-analysis, the sample size might be too small to reveal this result (13$15,33,46,48-50)$. Contrarily, our meta-analysis revealed no significant difference between the unipedicular and bipedicular groups in pooled outcome analysis of postoperative adjacent-level fractures.

SF-36 is one of the most widely used principal standards to measure the outcome of patients with spinal disorders. Results of this analysis showed that unilateral kyphoplasty and bilateral kyphoplasty are comparable in most dimensionality concepts of SF-36 subscale scores in both short-term and long-term follow-up with the important exception that the unilateral approach was superior in short-term general health.

\section{Limitations}

There are some limitations to this study. Since only 6 studies with 563 patients were included, the sample size was still relatively small. As a result, some result values may lack power. The small number of studies also limits evaluation for publication bias. The quality of the included studies and GRADE of outcomes were unsatisfactory. There were inconsistencies in the observation time for some of the data which may have a negative influence on the reliability of important results. Confident outcomes will require a greater number of high quality RCTs. 


\section{Conclusion}

Unilateral and bilateral kyphoplasty share many comparable results in the treatment of OVCFs. Comparative results include the following: short-term and long-term VAS score, kyphotic angle reduction, restoration rate of anterior vertebral height, vertebral height loss rate, postoperative adjacent-level fractures, and most assessments of SF-36 parameters. Both unipedicular and bipedicular kyphoplasty are safe and effective surgical selections. However, when considering the reduced operative time, cement volume, cement leakage, radiation dose, and improved short-term general health as well as reduced hospitalization cost, unilateral kyphoplasty may prove to be the preferred surgical procedure. Any final recommendations however, will require additional high-quality $\mathrm{RCTs}$ with long-term follow-up.

\section{Acknowledgments}

This work was supported by grants from Jiangsu Provincial Special Program of Medical Science (BL2012004), Jiangsu Provincial Clinical Orthopedic Center, and The Priority Academic Program Development of Jiangsu Higher Education Institutions (PAPD).

\section{References}

1. Rachner TD, Khosla S, Hofbauer LC. Osteoporosis: now and the future. Lancet 2011; 377:1276-87.

2. Ge Z, Ma R, Chen Z, Zhang H, Ding $H$, Liang S, Suo Z. Uniextrapedicular kyphoplasty for the treatment of thoracic osteoporotic vertebral fractures. Orthopedics 2013; 36:e1020-4.

3. Kumar K, Verma AK, Wilson J, LaFontaine A. Vertebroplasty in osteoporotic spine fractures: a quality of life assessment. Can J Neurol Sci 2005; 32:487-95.

4. Yan L, Jiang R, He B, Liu T, Hao D. A comparison between unilateral transverse process-pedicle and bilateral puncture techniques in percutaneous kyphoplasty. Spine 2014; 39:B19-26.

5. Yang H, Liu T, Zhou J, Meng B, Wang G, Zhu X. Kyphoplasty versus vertebroplasty for painful osteoporotic vertebral compression fractures-which one is better? A systematic review and meta-analysis. Int J Spine Surg 2013; 7:e45-57.

6. Xing D, Ma JX, Ma XL, Wang J, Xu WG, Chen $Y$, Song DH. A meta-analysis of balloon kyphoplasty compared to percutaneous vertebroplasty for treating osteoporotic vertebral compression fractures. J Clin Neurosci 2013; 20:795-803.

7. Gu CN, Brinjikji W, Evans AJ, Murad $\mathrm{MH}$, Kallmes DF. Outcomes of vertebroplasty compared with kyphoplasty: a systematic review and meta-analysis. J Neurointerv Surg 2015; doi: 10.1136/ neurintsurg-2015-011714.

8. Chang X, Lv YF, Chen B, Li HY, Han XB, Yang K, Zhang W, Zhou Y, Li CQ. Vertebroplasty versus kyphoplasty in osteo- porotic vertebral compression fracture: a meta-analysis of prospective comparative studies. Int Orthop 2015; 39:491-500.

9. Wang $H$, Sribastav SS, Ye F, Yang C, Wang J, Liu H, Zheng Z. Comparison of Percutaneous Vertebroplasty and Balloon Kyphoplasty for the Treatment of Single Level Vertebral Compression Fractures: A Meta-analysis of the Literature. Pain Physician 2015; 18:209-22.

10. Wang H, Sun Z, Wang Z, Jiang W. Single-balloon versus double-balloon bipedicular kyphoplasty for osteoporotic vertebral compression fractures. J Clin Neurosci 2015; 22:680-4.

11. Steinmann J, Tingey CT, Cruz G, Dai Q. Biomechanical comparison of unipedicular versus bipedicular kyphoplasty. Spine 2005; 30:201-5.

12. Wang Z, Wang G, Yang $\mathrm{H}$. Comparison of unilateral versus bilateral balloon kyphoplasty for the treatment of osteoporotic vertebral compression fractures. J Clin Neurosci. 2012; 19:723-6.

13. Lin J, Zhang L, Yang HL. Unilateral versus bilateral balloon kyphoplasty for osteoporotic vertebral compression fractures. Pain Physician 2013; 16:447-53.

14. Yang LY, Wang XL, Zhou L, Fu Q. A systematic review and meta-analysis of randomized controlled trials of unilateral versus bilateral kyphoplasty for osteoporotic vertebral compression fractures. Pain Physician 2013; 16:277-90.

15. Huang Z, Wan S, Ning L, Han S. Is unilateral kyphoplasty as effective and safe as bilateral kyphoplasties for osteoporotic vertebral compression fractures?
A meta-analysis. Clin Orthop Relat Res 2014; 472:2833-42.

16. Moher D, Liberati A, Tetzlaff J, Altman DG. Preferred reporting items for systematic reviews and meta-analyses: the PRISMA statement. BM] 2009; 339:b2535.

17. Bero L, Rennie D. The Cochrane Collaboration. Preparing, maintaining, and disseminating systematic reviews of the effects of health care. JAMA 1995; 274:1935-8.

18. Higgins J, Green S. Cochrane Handbook for Systematic Reviews of Interventions Version 5.1.0. The Cochrane Collaboration. http://wwwcochrane-handbook. org. Accessed May 1, 2015.

19. Atkins D BD, Briss PA, Eccles M, FalckYtter Y, Flottorp S, Guyatt GH, Harbour RT, Haugh MC, Henry D, Hill S, Jaeschke R, Leng G, Liberati A, Magrini $\mathrm{N}$, Mason J, Middleton P, Mrukowicz J, O'Connell D, Oxman AD, Phillips B, Schünemann $H$ J, Edejer T, Varonen $H$, Vist GE, Williams JW Jr, Zaza S; GRADE Working Group. Grading quality of evidence and strength of recommendations. BMJ 2004; 328:1490.

20. Chan H, Bolosan S, Simon R. Bilateral versus unilateral approach to balloon kyphoplasty... does it matter? Cardiovasc Intervent Radiol 2011; 34:541.

21. Chen B, Li Y, Xie D, Yang X, Zheng Z. Comparison of unipedicular and bipedicular kyphoplasty on the stiffness and biomechanical balance of compression fractured vertebrae. Eur Spine J 2011; 20:1272-80. 
22. Cho SM, Nam YS, Cho BM, Lee SY, Oh SM, Kim MK. Unilateral extrapedicular vertebroplasty and kyphoplasty in lumbar compression fractures: Technique, anatomy and preliminary results. J Korean Neurosurg Soc 2011; 49:273-7.

23. Higgins KB, Harten RD, Langrana NA, Reiter MF. Biomechanical effects of unipedicular vertebroplasty on intact vertebrae. Spine 2003; 28:1540-7.

24. Kallmes DF. Biomechanical effects of unipedicular vertebroplasty on intact vertebrae - Point of view. Spine 2003; 28:1548-.

25. Kobayashi K, Takizawa K, Koyama M, Yoshimatsu M, Sakaino S, Nakajima Y. Unilateral transpedicular percutaneous vertebroplasty using puncture simulation. Radiat Med 2006; 24:187-94.

26. Tohmeh AG, Mathis JM, Fenton DC, Levine AM, Belkoff SM. Biomechanical efficacy of unipedicular versus bipedicular vertebroplasty for the management of osteoporotic compression fractures. Spine 1999; 24:1772-6.

27. Voronov LI, Vastardis G, Marjan A, Stojanovic M, Dial B, Potluri T, Carandang G, Hadjipavlou A, Zindrick MR, Patwardhan AG. Feasibility of balloon kyphoplasty using unilateral transpedicular approach for the mid \& upper thoracic spine: A laboratory study. Spine J 2013; 13:151S-2S.

28. Chang WS, Lee S-H, Choi WG, Choi G, Jo B-J. Unipedicular vertebroplasty for osteoporotic compression fracture using an individualized needle insertion angle. Clin J Pain 2007; 23:767-73.

29. Hoh BL, Rabinov JD, Pryor JC, Hirsch JA. Ballon kyphoplasty for vertebral compression fracture using a unilateral balloon tamp via a uni-pedicular approach: Technical note. Pain physician. 2004; 7:111-4.

30. Hu MM, Eskey CJ, Tong SC, Nogueira RG, Pomerantz SR, Rabinov JD, Pryor JC, Hirsch JA. Kyphoplasty for vertebral compression fracture via a uni-pedicular approach. Pain Physician 2005; 8:363-7.

31. Pua U, Quek LHH, Ng LCL. Central stentoplasty: Technique for unipedicular single midline vertebral body stent implantation. Cardiovasc Intervent Radiol 2014; 37:810-4.

32. Wiwanitkit V. Unipedicular baloon kyphoplasty. Asian Spine J 2011; 5:277.
33. Chen H, Tang P, Zhao Y, Gao Y, Wang Y. Unilateral versus bilateral balloon kyphoplasty in the treatment of osteoporotic vertebral compression fractures. Orthopedics 2014; 37:e828-e35.

34. Li LH, Sun TS, Liu Z, Zhang JZ, Zhang $\mathrm{Y}$, Cai YH, Wang H. Comparison of unipedicular and bipedicular percutaneous kyphoplasty for treating osteoporotic vertebral compression fractures: A meta-analysis. Chin Med J (Engl) 2013; 126:3956-61.

35. Song BK, Eun JP, Oh YM. Clinical and radiological comparison of unipedicular versus bipedicular balloon kyphoplasty for the treatment of vertebral compression fractures. Osteoporosis Int 2009; 20:1717-23.

36. Lee SB, Cho KS, Huh PW, Yoo DS, Kang SG, Kim DS, Park CK. Clinical and radiographic results of unilateral transpedicular balloon kyphoplasty for the treatment of osteoporotic vertebral compression fractures. Acta Neurochir Suppl 2008; 101:157-60.

37. McGraw J, McGraw J. Prospective evaluation of a unipedicular technique utilizing balloon kyphoplasry and vertebroplasty for the treatment of symptomatic vertebral body compression fractures. J Vasc Interv Radiol 2015; 26:S205.

38. Papadopoulos EC, Edobor-Osula F, Gardner MJ, Shindle MK, Lane JM. Unipedicular balloon kyphoplasty for the treatment of osteoporotic vertebral compression fractures: early results. J Spinal Disord Tech 2008; 21:589-96.

39. Timon S, Gardner M, Hong RE, Lane JM. Unipedicular kyphoplasty for treatment of vertebral compression fractures. J Bone Miner Res 2003; 18:S381-S.

40. Trainor M. Unipedicular approach to percutaneous vertebral augmentation. Spine ] 2011; 11:132S.

41. Walz M, Esmer E, Kolbow B. CT-based analysis of cement distribution in unipedicular vertebroplasty. Unfallchirurg 2006; 109:932-9.

42. Wang S, Wang Q, Kang J, Xiu P, Wang $G$. An imaging anatomical study on percutaneous kyphoplasty for lumbar via a unilateral transverse process-pedicle approach. Spine 2014; 39:701-6.

43. La Maida GA, Sala F, Callea G, Capitani D, Singh S. Efficacy of unipedicular baloon kyphoplasty for treatment of multiple myeloma vertebral lesions. Asian Spine J 2011; 5:162-8.

44. Papanastassiou I, El Eraky M, Aghayev K, Vrionis F. Comparison of unilateral versus bilateral kyphoplasty in cancerrelated vertebral fractures. Spine J 2011; 11:8S.

45. Papanastassiou ID, Eleraky M, Murtagh R, Kokkalis ZT, Gerochristou M, Vrionis FD. Comparison of Unilateral versus Bilateral Kyphoplasty in Multiple Myeloma Patients and the Importance of Preoperative Planning. Asian Spine J 2014; 8:244-52.

46. Chen C, Chen L, Gu Y, Xu Y, Liu Y, Bai X, Zhu X, Yang H. Kyphoplasty for chronic painful osteoporotic vertebral compression fractures via unipedicular versus bipedicular approachment: A comparative study in early stage. Injury 2010; 41:356-9.

47. Chen C, Wei H, Zhang W, Gu Y, Tang G, Dong R, Xu Y, Chen L. Comparative study of kyphoplasty for chronic painful osteoporotic vertebral compression fractures via unipedicular versus bipedicular approach. Journal of Spinal Disorders and Techniques 2011; 24:E62-E5.

48. Chen L, Yang H, Tang T. Unilateral versus bilateral balloon kyphoplasty for multilevel osteoporotic vertebral compression fractures: A prospective study. Spine 2011; 36:534-40.

49. Chung HJ, Chung KJ, Yoon HS, Kwon IH. Comparative study of balloon kyphoplasty with unilateral versus bilateral approach in osteoporotic vertebral compression fractures. Int Orthop 2008; 32:817-20.

50. Rebolledo BJ, Gladnick BP, Unnanuntana A, Nguyen JT, Kepler CK. Comparison of unipedicular and bipedicular balloon kyphoplasty for the treatment of osteoporotic vertebral compression fractures a prospective randomised study. Bone and Joint Journal 2013; 95B:401-6.

51. Lau J, loannidis JP, Terrin N, Schmid $\mathrm{CH}$, Olkin I. The case of the misleading funnel plot. BMJ 2006; 333:597-600.

52. Frankel BM, Monroe T, Wang C. Percutaneous vertebral augmentation: an elevation in adjacent-level fracture risk in kyphoplasty as compared with vertebroplasty. Spine J 2007; 7:575-582. 
